\title{
Genetic variability in the precore and core promoter regions of hepatitis B virus strains in Karachi Zaigham Abbas*1, Rana Muzaffar ${ }^{2}$, Arif Siddiqui ${ }^{1}$, Syed Ali Anwar Naqvi ${ }^{1}$ and Syed Adibul Hassan Rizvi ${ }^{1}$
}

Address: ${ }^{1}$ Department of Hepatogastroenterology, Sindh Institute of Urology and Transplantation, Karachi, Pakistan and ${ }^{2}$ Department of Molecular Biology, Sindh Institute of Urology and Transplantation, Karachi, Pakistan

Email: Zaigham Abbas* - zaigham@akunet.org; Rana Muzaffar - rmuzafar@super.net.pk; Arif Siddiqui - info@siut.org; Syed Ali Anwar Naqvi - siutpk@sat.net.pk; Syed Adibul Hassan Rizvi - siutpk@sat.net.pk

* Corresponding author

Published: 24 July 2006

BMC Gastroenterology 2006, 6:20 doi:10.1 I86/147/-230X-6-20
Received: 18 December 2005

Accepted: 24 July 2006

This article is available from: http://www.biomedcentral.com/I47I-230X/6/20

(C) 2006 Abbas et al; licensee BioMed Central Ltd.

This is an Open Access article distributed under the terms of the Creative Commons Attribution License (http://creativecommons.org/licenses/by/2.0), which permits unrestricted use, distribution, and reproduction in any medium, provided the original work is properly cited.

\begin{abstract}
Background: Hepatitis B virus (HBV) genotypes have distinct geographic distribution. Moreover, much genetic variability has been described in the precore (PC) and basal core promoter (BCP) regions of the HBV genome. The local prevalence of HBV genotypes and mutations has not been well studied. The aim of the present study is to determine the prevalence of HBV genotypes and mutations in the $\mathrm{PC}$ and $\mathrm{BCP}$ region in HBV strains in Karachi.
\end{abstract}

Methods: A total of 109 chronic hepatitis B patients with detectable HBV DNA by a PCR assay were enrolled in the study. Sera were tested for $\mathrm{HBeAg}$, anti-HBe antibody and liver profile. HBV genotypes and mutations in the PC and BCP regions were detected by INNO-LiPA line-probe assays.

Results: Of the 109 patients investigated, 38 (35\%) were $\mathrm{HBeAg}$ positive while 7I (65\%) were HBeAg negative. Genotype D was present in $100 \%$ of the patients. Two patients had co-infection with genotype $A$. There was no significant difference in the baseline characteristics, mean ALT levels, and presence of clinical cirrhosis in patients with $\mathrm{HBeAg}$ positive or negative strains with or without PC and BCP mutations. Of the $38 \mathrm{HBeAg}$ positive patients, $9(24 \%)$ had PC and BCP mutations. In the $\mathrm{HBeAg}$ negative patient group, mutations were detected in $44(62 \%)$ of the strains investigated. More than one mutation was common, seen in $26(37 \%)$ patients with $\mathrm{HBeAg}$ negative disease and 6 (16\%) patients with $\mathrm{HBeAg}$ positive disease. Twelve (17\%) HBeAg negative patients had dual TI762 and AI764 mutations. None of the HBeAg positive patients had TI762 mutation. Mutations were undetectable in $27(38 \%)$ of patients with $\mathrm{HBeAg}$ negative disease.

Conclusion: Our study shows that type D is the main HBV genotype in Karachi, Pakistan. Significant numbers of patients infected with this genotype have PC and BCP variants. Mutations at more than one site are common. Patients harboring these mutants do not differ significantly in their clinical presentation from patients having wild type infection. 


\section{Background}

Hepatitis B Virus (HBV) is a well-known agent of acute and chronic hepatitis, liver cirrhosis and hepatocellular carcinoma. Around 400 million people worldwide carry the virus of which more than 250 million reside in Asia [1].

HBV has been classified into eight genotypes (A-H) according to the criterion of $=8 \%$ differences in the complete nucleotide sequence of the viral genome [2-5]. These genotypes show variation in their geographic distribution [4,6-8]. In addition to the epidemiological importance, these genotypes may influence the disease pattern and response to treatment.

In the natural course of chronic HBV infection, the loss of HBeAg expression and the appearance of antibodies directed against it (Anti-HBe) are usually accompanied by cessation of viral replication. However such a serology profile may also be seen in individuals who harbor precore (PC) and basal core promoter (BCP) mutants where replicative infection continues. The frequent genomic mutation that leads to HBeAg negativity is the mutation of the nucleotide (nt) 1896 from G to A (G-A). This mutation converts codon 28 of the precore sequence to a termination codon (TGG $\rightarrow$ TAG) and thus prevents HBeAg from being expressed [9]. PC variants are more common among patients with genotype $\mathrm{D}$ ( 65 to 75 percent) than genotype A ( 9 to 18 percent) $[10,11]$.

A second group of mutations affect the basal core promoter region and result in a transcriptional reduction of precore but not pregenomic and core mRNA [12]. These HBeAg suppressive strains contain mutations of nt1762 from A to T (A 1762 T) and nt 1764 from G to A (G 1764 $\mathrm{A})$ in the BCP region and are the predominant quasispecies in chronic hepatitis patients [13-16]. These mutations may be found in isolation or in conjunction with PC mutations. Occurrence of these mutations result in increase in viral load $[12,13,17,18]$. These changes were initially thought to be related to a "HBeAg-negative phenotype" but recent studies showed that they may also be found in some HBeAg-positive patients, especially those with chronic hepatitis $[14,19]$.

The present study aimed to determine the HBV genotypes in Karachi and the pattern of PC and BCP mutations. This is the first study reporting the details of the $\mathrm{PC}$ and $\mathrm{BCP}$ mutants from Pakistan.

\section{Methods}

Included in this study were 109 patients who visited the liver clinic of our institute for further evaluation and fulfilled the following criteria (1) HBsAg positive for more than six months (2) HBV DNA positive (3)No other con- comitant liver diseases including hepatitis $\mathrm{C}$ and HIV infections, autoimmune hepatitis, Wilson's disease, primary biliary cirrhosis, alcoholic liver disease and nonalcoholic fatty liver disease (4) No previous treatment for hepatitis B. Demographic and clinical data of these patients was recorded. Ethics Review Committee of the hospital (SIUT) approved the protocol (see Additional file $1)$.

Informed consent was taken from patients fulfilling the inclusion criteria and blood samples taken. They were tested for alanine aminotransferase (ALT), alkaline phosphatase (ALP), serum albumin, bilirubin. Hepatitis B serological markers were tested by micro-ELISA method (AxSYM, Abbott laboratories, North Chicago, IL USA). HBV DNA was extracted from $200 \mu \mathrm{l}$ of serum using QIAamp DNA Blood Mini Kit (Qiagen GmbH, Germany) and amplified by an in-house PCR assay with a detection limit of 1000 geq./ml. The primers used were P7 (5'-GTG GTG GAC TTC TCT CAA TTT TC-3' nt. 256-278) and S12 (5'-CGA ACC ACT GAA CAA ATG GC-3' nt. 685-704 [20].

HBV DNA positive samples were analyzed for viral genotypes and mutations in the PC and BCP regions. We used commercially available Line Probe Assays for HBV genotyping and mutation analysis (INNOGENETICS, Belgium) $[11,21,22]$. INNO-LiPA PreCore kit detects mutations in PC codon 28, and BCP nt 1762 and nt 1764 . The kit can detect a wild type/mutant mixed population of circulating virus in contrast to sequencing which would only identify the predominant variant.

The patients were labeled suffering from clinical cirrhosis on the basis of clinical and ultrasound findings suggestive of cirrhosis (nodular surface, firm consistency, blunt liver edge, altered echotexure, dilated portal vein and splenomegaly) and evidence of hypersplenism (platelets $<100,00 /$ $\left.\mathrm{mm}^{3}\right)$.

\section{Statistical analysis}

The corrected chi-square test was used to compare categorical data. Student $t$ test or one-way analysis of variance was used for group comparisons of parametric quantitative data and the Mann-Whitney test for similar comparisons of nonparametric data. In all cases, tests of significance were two-tailed, with a level at less than 0.05. Results are presented as median (range) or mean \pm SD, whenever appropriate. Statistical analysis was done with the statistical package SPSS for Windows 2000 (version 10.1, SPSS, Chicago, IL).

\section{Results}

Our study population included 109 HBV DNA positive chronic hepatitis $\mathrm{B}$ patients. The mean age of these 
patients was $32.6 \pm 11.9$ years (range $7-70$ years). Eighty five $(78 \%)$ patients were male. Thirty eight patients (35\%) were $\mathrm{HBeAg}$ positive and 71 (65\%) HBeAg negative. All the HbeAg negative patients and one HBeAg positive patients had Anti-HBe antibody positive. All of the samples belonged to genotype $\mathrm{D}$ except two patients who were coinfected with genotype A. Characteristics of these patients are given in Table 1 . There was no difference in terms of sex, age, biochemical profile and clinical cirrhosis in HBeAg positive and negative variants.

Mutations in the PC and BCP regions were detected in 9 (24\%) of HBeAg positive patients and 44 (62\%) of HBeAg negative patients $(\mathrm{p}=000)$. Remaining patients had the wild type band for both PC and BCP regions in the line probe assay. BCP mutations were found in $45(41 \%)$ patients; $8(21 \%)$ in HbeAg positive and $37(52 \%)$ in HBeAg negative group. PC mutations were found in 7 $(18 \%)$ and $22(31 \%)$ of HbeAg positive and negative patients. Details of individual mutations are given in Table 2. More than one mutation was common, seen in $26(37 \%)$ patients with HBeAg negative disease and 6 (16\%) patients with HBeAg positive disease. Twelve (17\%) HBeAg negative patients had dual T1762 and A1764 mutations. None of the HBeAg positive patients had T1762 mutation. Mutations were undetectable in 27 (38\%) of patients with HBeAg negative disease.

The patients with wild type virus were younger than the patients having mutant type virus in HBeAg negative group (age $27.8 \pm 9.6$ vs $38.3 \pm 12.9, p=0.012$ ). There were no statistical differences in the laboratory parameters and presence of clinical cirrhosis in patients harboring the wild virus compared to the mutant variant in both HBeAg negative and positive groups. Patients with normal ALT at the time of presentation did not differ from patients with elevated ALT in the frequency of different mutations.

\section{Discussion}

All of our patients had genotype $\mathrm{D}$ with two patients coinfected with type A. This pattern is unique when compared to those of other countries in Asia. In South East Asia, genotypes B and C are highly prevalent [23] and in India a mixed pattern of genotypes $\mathrm{D}, \mathrm{A}$ and $\mathrm{C}$ is seen $[24,25]$. There are therapeutic implications of this finding as patients with genotype D have more severe disease [26] and are less responsive to interferon therapy as compared to genotype A and B $[27,28]$ and have higher HBV DNA levels (8). Moreover, in this genotype, specific viral sequence patterns present before initiation of therapy appear to be predictive of long-term response to lamivudine treatment [29].

The incidence of HBeAg negative chronic hepatitis B has increased in many countries [30]. In our study HBeAg negative patients predominated. This does not represent the true prevalence of the HBeAg negative disease as the samples were collected by convenience sampling. However, it does signify its high prevalence. Information about prevalence of PC and BCP mutations is also important in terms of response to interferon, development of fulminant hepatitis, rate of lamivudine resistant mutants and development of hepatocellular carcinoma [31]. Studies have shown that the PC variant is more prevalent among

Table I: Characteristics of patients, HBV genotypes and mutant

\begin{tabular}{|c|c|c|c|}
\hline & $\begin{array}{c}\text { HBeAg Negative Patients }(n= \\
7 \mid)\end{array}$ & $\begin{array}{c}\text { HBeAg Positive Patients }(n= \\
38)\end{array}$ & $p$ value \\
\hline $\operatorname{Sex}(M / F)$ & $57 / 14$ & $28 / 10$ & 0.428 \\
\hline Age (Yrs) & $33.8 \pm 12.6$ & $31.4 \pm 11.5$ & 0.464 \\
\hline Serum bilirubin (mg/dl) & $1.4 \pm 2.9$ & $0.9 \pm 0.8$ & 0.247 \\
\hline $\mathrm{ALT}(\mathrm{U} / \mathrm{L})$ & $61 \pm 79$ & $93 \pm 137$ & 0.236 \\
\hline Alkaline phosphatase (U/L) & $169 \pm 124$ & $195 \pm 169$ & 0.450 \\
\hline Serum Albumin $(g / d l)$ & $3.5 \pm 1.0$ & $3.6 \pm 1.1$ & 0.714 \\
\hline Platelet count $\left(10^{6} / \mu \mathrm{L}\right)$ & $179 \pm 76$ & $|7| \pm 80$ & 0.751 \\
\hline Clinical cirrhosis & 16 & 06 & 0.717 \\
\hline Genotype D* & 71 & 38 & 1.000 \\
\hline Coinfection with genotype & 00 & 02 & \\
\hline \multicolumn{4}{|l|}{ Mutations } \\
\hline Precore GI896A & 22 & 07 & 0.157 \\
\hline BCP AI762T & 11 & 00 & $0.010^{ل}$ \\
\hline BCP GI764A & 27 & 06 & $0.016^{V}$ \\
\hline Absent wild PC band & 22 & 05 & $0.040^{\vee}$ \\
\hline Absent wild $\mathrm{BCP}$ band & 34 & 07 & $0.002^{\downarrow}$ \\
\hline Overall mutants** & 44 & 09 & $0.000^{V}$ \\
\hline More than one mutations & 26 & 06 & $0.023^{\vee}$ \\
\hline
\end{tabular}

*Genotype $\mathrm{D}$ present in all the patients. **More than one mutations in many patients. PC: precore, BCP: basal core promoter. ${ }^{\vee}$ Significant $p$ values 
Table 2: Details of precore (PC) and basal core promotor (BCP) mutations as detected by line probe assays for PC I896, BCP I762, $B C P 1764$ and wild $P C$ and $B C P$ regions $(n=53)$

\begin{tabular}{ll}
\hline HBeAg Negative Patients $(\mathbf{n}=\mathbf{4 4})$ & $\mathbf{n}$ \\
\hline PC (1896) alone & 03 \\
BCP I762 alone & 01 \\
BCP I764 alone & 08 \\
PC + I764 & 06 \\
BCP I762 + I764 & 03 \\
PC + I762 + I764 & 06 \\
PC + presence of wild PC band & 02 \\
PC + BCP I762 + BCP I764 + presence of wild PC band & 02 \\
Absent wild BCP band alone* & 04 \\
Absent PC wild band* & 02 \\
PC + absent wild BCP band & 02 \\
Miscellaneous combinations & 05 \\
HBeAg Positive Patients $(\mathbf{n}=9)$ & 04 \\
BCP I764 + PC & 01 \\
BCP I764 alone & 01 \\
Absent wild BCP band alone* & 03 \\
Miscellaneous combinations & \\
\hline
\end{tabular}

$\mathrm{PC}=$ precore, $\mathrm{BCP}=$ basal core promoter

*Wild band and specified mutation bands absent. Thus mutations not detected by LiPA

patients with genotype $\mathrm{D}$, the type found in our patients, than in type A [10,11]. This mutation (G1896A) stabilizes the epsilon structure in the PC gene by forming a base pair with $n 1858$ which exists as $T$ in this genotype [32]. Treating these patients with interferon results in high relapse rates $[33,34]$.

$62 \%$ of our HBeAg negative patients and $24 \%$ of $\mathrm{HBeAg}$ positive patients had PC and BCP mutants $(\mathrm{p}=000)$ so the frequency was more in those who did not express HBeAg. Combining HBeAg positive and negative groups PC variants were present in $29(27 \%)$ and BCP variants in $44(40 \%)$ patients. There was an overlap with mutations present at more than one site. There are some reports of association of PC mutation with fulminant hepatic failure [35] and the BCP variants with more severe liver damage [36-39] and HCC [40-43]. Other workers could not confirm a specific mutation predicting fulminant disease [44]. BCP mutations may not be necessarily pathogenic as they have been found in acute self limiting hepatitis, chronic hepatitis and asymptomatic carriers [45]. In our study, ALT levels and prevalence of clinical cirrhosis did not differ significantly in patients without or with PC or BCP mutants in both HBeAg negative and positive subgroups. Clinical relevance of these variants may be overstated and any correlation of nucleotide sequences with clinical and serologic findings must be done with precaution [46].

Studies from Asia suggested that the dual core promoter variant (A1762T, G1764A) was more common in patients with genotype $C$ than those with genotype $B[37,47]$.
Double mutation may enhance viral replication [13]. In our study most of the patients had HBV mutations at more than one sites. Twelve (17\%) HBeAg negative patients had dual T1762 and A1764 mutations. None of the HBeAg positive patients had T1762 mutation.

In some of our patients though the line probe assay could not detect a specific mutation at 1762, 1764, and 1896 position but the wild PC or BCP band was absent. The samples were retested and the control bands worked in each run. This raises the possibility of other mutations in these regions undetected by INNO-LiPA (Table 2). It would be worthwhile investigating further these patients as it has been shown that three other nucleotide mutations at position $1817,1874,1897$ also cause truncation in HBeAg and other changes that affect initiation codon at 1814,1815 and 1816 have also been reported [48]. Moreover certain deletion mutations will not be detected by INNO-LiPA. Bozdayi et al [49] showed the existence of considerable variability between nucleotides 1751-1775 of the core promoter region in genotype $\mathrm{D}$. Twenty seven $(38 \%)$ of our HBeAg negative patients did not show any mutation by the assay we used.

Twenty four percent of our HBeAg positive patients had PC and BCP mutations. HBeAg did not disappear even in the presence of PC mutation. It may be due to presence of a mixed infection with the mutant and wild type viruses. Presence of wild type virus is needed by some of the mutants such as deletion mutants within the core promoter and core gene as well as variants with large deletions for infection of hepatocytes as shown for the 
woodchuck hepatitis virus [50]. It appears that HBV exists as a quasi species of wild type and mutant clones even in the HBeAg positive phase [46]. Direct sequencing can not detect a mutant population unless it accounts for a majority of the total population while INNO-LiPA assay is able to pick up the mixed infection.

Davidson F, et al compared the line probe assay we used with direct sequence analysis and found it more sensitive in detecting mixed infection. PC and BCP mutants were detected in three-fourth $(74 \%)$ of patients with genotype $\mathrm{D}$ [51]. These mutations were picked up in half $(49 \%)$ of cases in our study. In a study done by sequence analysis of Turkish patients with genotype $\mathrm{D}, \mathrm{BCP}$ mutations were found in $17 \%$ and $29 \%$ of HbeAg positive and negative patient [49]. Our data suggests the figure of $21 \%$ and $52 \%$. Perhaps geographical differences, host factors and type of assay used may influence the outcome.

\section{Conclusion}

In conclusion, genotype D is the main HBV genotype in Karachi, Pakistan and significant number of our patients have PC and BCP variants. Patients harboring these mutants do not differ significantly in their clinical presentation from patients having wild type infection.

\section{Competing interests}

The author(s) declare that they have no competing interests.

\section{Authors' contributions}

ZA conceived of the study, wrote the protocol, coordinated different activities, did the statistical analysis and wrote the manuscript. RM performed assays and molecular studies, and helped in writing the manuscript and its revision. AS performed the data collection. SAAN helped with study design, contributed patients and revised manuscript. SAHR helped with the draft of manus and contributed patients. All authors read and approved the final manuscript.

\section{Acknowledgements}

This study was supported by the grant of the Research Committee of Sindh Institute of Urology and Transplantation.

\section{References}

I. Lee WM: Hepatitis B virus infection. N Engl J Med 1997, 337:1733-1745.

2. Okamoto H, Tsuda F, Sakugawa H, Sastrosoewignjo RI, Imai M, Miyakawa $Y$, Mayumi M: Typing hepatitis B virus by homology in nucleotide sequence: comparison of surface antigen subtypes. I Gen Virol 1988, 69:2575-2583.

3. Norder H, Courouce AM, Magnius LO: Complete genomes, phylogenetic relatedness, and structural proteins of six strains of the hepatitis B virus, four of which represent two new genotypes. Virology 1994, 198:489-503.

4. Stuyver L, De Gendt S, Van Geyt C, Zoulim F, Fried M, Schinazi RF, Rossau R: A new genotype of hepatitis $B$ virus: complete genome and phylogenetic relatedness. J Gen Virol 2000, 8 I (Pt I):67-74.

5. Arauz-Ruiz P, Norder H, Robertson BH, Magnius LO: Genotype H: a new Amerindian genotype of hepatitis $B$ virus revealed in Central America. J Gen Virol 2002, 83:2059-2073.

6. Norder H, Hammas B, Lee SD, Bile K, Courouce AM, Mushahwar IK, Magnius LO: Genetic relatedness of hepatitis B viral strains of diverse geographical origin and natural variations in the primary structure of the surface antigen. J Gen Virol 1993, 74(Pt 7): $1341-1348$.

7. Lindh M, Andersson AS, Gusdal A: Genotypes, nt 1858 variants, and geographic origin of hepatitis B virus - large-scale analysis using a new genotyping method. J Infect Dis 1997, I75: 1285-I293.

8. Westland C, Delaney W 4th, Yang H, Chen SS, Marcellin P, Hadziyannis S, Gish R, Fry J, Brosgart C, Gibbs C, Miller M, Xiong S: Hepatitis $B$ virus genotypes and virologic response in 694 patients in phase III studies of adefovir dipivoxil. Gastroenterology 2003, 125:107-116.

9. Lok AS, Akarca U, Greene S: Mutations in the pre-core region of hepatitis B virus serve to enhance the stability of the secondary structure of the pre-genome encapsidation signal. Proc Natl Acad Sci USA 1994, 91:4077-408I.

10. Rodriguez-Frias F, Buti M, Jardi R, Cotrina M, Viladomiu L, Esteban R, Guardia J: Hepatitis B virus infection: Precore mutants and its relation to viral genotypes and core mutations. Hepatology 1995, 22:164|-1647.

II. Grandjacques C, Pradat P, Stuyver L, Chevallier M, Chevallier P, Pichoud C, Maisonnas M, Trepo C, Zoulim F: Rapid detection of genotypes and mutations in the pre-core promoter and the pre-core region of hepatitis $B$ virus genome: correlation with viral persistence and disease severity. J Hepatol 2000, 33:430-439.

12. Hunt CM, McGill JM, Allen MI, Condreay LD: Clinical relevance of hepatitis B virus mutations. Hepatology 2000, 31:1037-1044.

13. Buckwold EV, Xu Z, Yen TS, Ou JH: Effects of double nucleotide basal core promoter mutation and its putative single-nucleotide precursor mutations on hepatitis $B$ virus gene expression and replication. J Gen Virol 1997, 78:2055-2065.

14. Okamoto H, Tsuda F, Akahane Y, Sugai Y, Yoshiba M, Moriyama K, Tanaka T, Miyakawa Y, Mayumi M: Hepatitis B virus with mutations in the core promoter for an e antigen-negative phenotype in carriers with antibody to e antigen. J Virol 1994, 68:8102-8110.

15. Takahashi K, Aoyama K, Ohno N, Iwata K, Akahane Y, Baba K, Yoshizawa $\mathrm{H}$, Mishiro S: The precore/core promoter mutant (TI762A 1 764) of hepatitis B virus: Clinical significance and an easy method for detection. J Gen Virol 1995, 76(Pt 12):3159-3164.

16. Kurosaki M, Enomoto N, Asahina $Y$, Sakuma I, Ikeda T, Tozuka S, Izumi N, Marumo F, Sato C: Mutations in the core promoter region of hepatitis $B$ virus in patients with chronic hepatitis B. J Med Virol 1996, 49: II5-123.

17. Buckwold VE, Xu Z, Chen M, Yen TS, Ou JH: Effects of a naturally occurring mutation in the hepatitis $B$ virus basal core promoter on precore gene expression and viral replication. J Virol 1996, 70:5845-585।.

18. Moriyama K, Okamoto H, Tsuda F, Mayumi M: Reduced precore transcription and enhanced core-pregenome transcription of hepatitis B virus DNA after replacement of the precorecore promoter with sequences associated with e antigenseronegative persistent infections. Virology 1996, 226:269-280.

19. Kidd-Ljunggren $K$, Oberg $M$, Kidd $A H$ : Hepatitis $B$ virus $\times$ gene I75 I to 1764 mutations: Implications for $\mathrm{HBeAg}$ status and disease. J Gen Virol 1997, 78(Pt 6): I 469-I478.

20. Naito H, Hayashi S, Abe K: Rapid and specific genotyping system for Hepatitis B virus corresponding to six major genotypes by PCR using type-specific primers. J Clin Micobiol 200I, 39:362-364.

21. Hussain M, Chu CJ, Sablon E, Lok AS: Rapid and sensitive assays for determination of hepatitits B virus (HBV) genotypes and detection of $\mathrm{HBV}$ precore and core promoter variants. J Clin Microbiol 2003, 41:3699-3705.

22. Yuen MF, Sablon E, Yuan HJ, Hui CK, Wong DKH, Doutreloigne J, Wong BC, Chan AO, Lai CL: The relationship between the development of precore and core promoter mutations and 
HbeAg seroconversion in chronic hepatitis B. J Infect Dis 2002, 186: I335-1338.

23. Wong GL, Chan HL: Molecular virology in chronic hepatitis B: genotypes. Hosp Med 2005, 66:13-16.

24. Gandhe SS, Chadha MS, Arankalle VA: Hepatitis B virus genotypes and serotypes in western India: lack of clinical significance. I Med Virol 2003, 69:324-330.

25. Kumar A, Kumar SI, Pandey R, Naik S, Aggarwal R: Hepatitis B virus genotype $A$ is more often associated with severe liver disease in northern India than is genotype $\mathbf{D}$. Indian J Gastroenterol 2005, 24: 19-22.

26. $\mathrm{KaO} \mathrm{JH}$, Liu CJ, Chen DS: Hepatitis B viral genotypes and lamivudine resistance. J Hepatol 2002, 36:303-304.

27. Sablon E, Shapiro F: Hepatitis $B$ and $C$ genotyping: methodologies and implications for patient management. J Gastroenterol Hepatol 2004, I9(suppl 7):S329-337.

28. Erhardt A, Reineke U, Blondin D, Gerlich WH, Adams O, Heintges T, Niederau C, Haussinger D: Mutations of the core promoter and response to interferon treatment in chronic replicative hepatitis B. Hepatology 2000, 3I:716-725

29. Ciancio A, Smedele A, Rizzetto M, Lagget M, Gerin J, Korba B: Identification of HBV DNA sequences that are predictive of response to lamivudine therapy. Hepatology 2004, 39:64-73.

30. Lok AS, Heathcote EJ, Hoofnagle JH: Management of hepatitis B: 2000-summary of a workshop. Gastroenterology 200I, 120:1828-1853.

31. Locarnini S: Relevance of HBV mutations in severity and progression of chronic hepatitis B. J Gastroenterol Hepatol 2004, 19:SI08-SII2.

32. Summers J, Mason WS: Replication of the genome of a hepatitis B - like virus by reverse transcription of an RNA intermediate. Cell 1982, 29:403-415

33. Brunetto MR, Giarin M, Saracco G, Oliveri F, Calvo P, Capra G, Radone A, Abate ML, Manzini P, Capalbo M, Piantino P, Verme G, Ferruccio $B$ : Hepatitis $B$ virus unable to secrete $e$ antigen and response to interferon in chronic hepatitis B. Gastroenterology 1993, 105:845-850.

34. Pastore G, Sanantonio T, Milella M, Monno L, Mariano N, Moschetta $R$, Pollice $L$ : Anti-HBe positive chronic hepastitis B with HBV DNA in the serum: response to a 6 month course of lymphoblastoid interferon. J Hepatol 1992, 14:221-225.

35. Liang T], Hasegawa K, Munoz SJ, Shapiro CN, Yoffe B, McMahon B], Feng C, Bei H, Alter MJ, Dienstag JL: Hepatitis B virus precore mutation and fulminant hepatitis in the United States. A polymerase chain reaction-based assay for the detection of specific mutation. J Clin Invest 1994, 93:550-5.

36. Shiina S, Fujino H, Uta Y, Tagawa K, Unuma T, Yoneyama M, Ohmori T, Suzuki S, Kurita M, Ohashi Y: Relationship of HBsAg subtypes with $\mathrm{HBeAg} / \mathrm{anti}-\mathrm{HBe}$ status and chronic liver disease. Part I: Analysis of 1744 HBsAg carriers. Am J Gastroenterol I99I, 86:866-87I.

37. Orito E, Mizokami M, Sakugawa H, Michitaka K, Ishikawa K, Ichida T, Okanoue T, Yotsuyanagi $\mathrm{H}$, lino S: A case-control study for clinical and molecular biological differences between hepatitis $B$ viruses of genotypes B and C. Japan HBV Genotype Research Group. Hepatology 2001, 33:218-223.

38. Takahashi K, Aoyama K, Ohno N, Iwata K, Akahane Y, Baba K, Yoshizawa $\mathrm{H}$, Mishiro S: The precore/core promoter mutant (TI762A1764) of hepatitis B virus: Clinical significance and an easy method for detection. J Gen Virol 1995, 76(Pt 12):3159-3164.

39. Sato S, Suzuki K, Akahane Y, Akamatsu K, Akiyama K, Yunomura K Tsuda F, Tanaka T, Okamoto H, Miyakawa Y, Mayumi M: Hepatitis $B$ virus strains with mutations in the core promoter in patients with fulminant hepatitis. Ann Intern Med 1995, 122:24I-248.

40. Chan HL, Leung NW, Hussain M, Wong ML, Lok AS: Hepatitis B e antigen-negative chronic hepatitis B in Hong Kong. Hepatology 2000, 31:763-768.

4I. Kao JH, Chen PJ, Lai MY, Chen DS: Basal core promoter mutations of hepatitis B virus increase the risk of hepatocellular carcinoma in hepatitis B carriers. Gastroenterology 2003, 124:327-334.

42. Fang ZL, Ling R, Wang SS, Nong J, Huang CS, Harrison TJ: HBV core promoter mutations prevail in patients with hepatocellular carcinoma from Guangxi, China. J Med Virol 1998, 56:18-24.
43. Baptista M, Kramvis A, Kew MC: High prevalence of I762(T) 1764(A) mutations in the basic core promoter of hepatitis $B$ virus isolated from black Africans with hepatocellular carcinoma compared with asymptomatic carriers. Hepatology 1999, 29:946-953.

44. Sterneck M, Gunther S, Santantonio T, Fischer L, Broelsch CE, Greten $\mathrm{H}$, Will $\mathrm{H}$ : Hepatitis B virus genomes of patients with fulminant hepatitis do not share a specific mutation. Hepatology 1996, 24:300-306.

45. Chun YK, Kim JY, Woo HJ, Oh SM, Kang I, Ha J, Kim SS: No significant correlation exists between core promoter mutations, viral replication, and liver damage in chronic hepatitis B infection. Hepatology 2000, 32:1 I54-1162.

46. Fukuda R, Mohammad R, Hamamoto S, Ishimura N, Ishihara S, Akagi $S$, Watanabe M, Kinoshita Y: Clinical relevance of precore and basal core promoter variants of hepatitis $B$ virus during natural hepatitis $B$ e antigen seroconversion may be overstated. J Pediatr Gastroenterol Nutr 200I, 33:30 I-306.

47. Lindh M, Hannoun C, Dhillon AP, Norkrans G, Horal P: Core promoter mutations and genotypes in relation to viral replication and liver damage in East Asian hepatitis B virus carriers. J Infect Dis 1999, 179:775-782.

48. Gunther S, Fischer L, Pult I, Sterneck M, Will H: Naturally occurring variants of hepatitis B virus (review). Adv Virus Res 1999, 52:25-I37.

49. Bozdayi AM, Bozkaya H, Turkyilmaz AR, Saryodlu M, Cetinkaya H, Karayalcin S, Yurdaydin C, Uzunalimoglu O: Nucleotide divergences in the core promoter and precore region of genotype D hepatitis B virus in patients with persistently elevated or normal ALT levels. J Clin Virol 2001, 21:91-101.

50. Zoulim F, Saputelli J, Seeger C: Woodchuck hepatitis virus $\times$ protein is required for viral infection in vivo. J Virol 1994 68:2026-2030.

5I. Davidson F, Lycett C, Sablon E, Petrik J, Dow BC: Hepatitis B virus genotypes and precore mutations in Scottish blood donors. Vox Sanguinis 2005, 88:87-92.

\section{Pre-publication history}

The pre-publication history for this paper can be accessed here:

http://www.biomedcentral.com/1471-230X/6/20/pre pub

Publish with Biomed Central and every scientist can read your work free of charge

"BioMed Central will be the most significant development for disseminating the results of biomedical research in our lifetime. "

Sir Paul Nurse, Cancer Research UK

Your research papers will be:

- available free of charge to the entire biomedical community

- peer reviewed and published immediately upon acceptance

- cited in PubMed and archived on PubMed Central

- yours - you keep the copyright
BiolMedcentral 